\title{
A REVIEW OF EXPERIMENTAL RESEARCH IN SPINAL CORD INJURY
}

\author{
By Dr John D. Yeo \\ Spinal Injury Unit, Royal North Shore Hospital of Sydney
}

Received: September 1975

IN recent years the long-held beliefs that regeneration in the central nervous system does not occur have been questioned. As early as 1915, regeneration within the central nervous system of amphibia was reported. The regenerative capacity of central nervous tissue has been shown to be greater in embryonic and newborn animals. Evidence of intraspinal sprouting in the dorsal root axons with the development of new collaterals and preterminals following partial denervation of the spinal cord was shown in the cat by Lui and Chambers (I958).

The difficulties associated with regeneration in central nervous tissue were reviewed by Windle (I955, I962). Following injury, the pathogenesis of concussion, contusion and laceration in the spinal cord of man was described by Bedbrook (1966).

Wolman (I966) reported the results of investigations carried out in 76 paraplegics, and detailed the findings at autopsy on each of these patients. Serial histological examination of spinal cord sections showed well-developed axon regeneration in or near the damaged segments in 12 of these patients; regeneration was demonstrated in spinal cords 12 months to 32 years after injury. These regenerating axons occurred in small bundles above and below the level of the maximum cord damage. The suggested origins of these axons were (i) the dorsal columns or (ii) the propriospinal system. It is still uncertain exactly where such regenerating fibres terminate or where they make their synapses.

In 1969, Professor W. F. Windle, addressing the Spinal Cord Injury Conference in the New York University Medical School, stated: 'There is little interest at the present time in spinal cord regeneration. The one word most commonly associated with this term is "impossible".'

However, since 1969 a number of institutions have taken up the challenge and clarified the pathogenesis of permanent paraplegia in man following a severe contusion injury to the spinal cord. Hughes has described the various pathological changes in the spinal cord following trauma (1966).

In attempting to compare the many reports on experimental spinal cord rauma, it is necessary to remember the importance of the reproducible and quantitative form of injury. There is accumulating evidence that moderate contusion of the spinal cord producing either transitory or permanent paraplegia results in structural, vascular, physiological and biochemical changes, some of which may be reversible (Allen, I9I I; Freeman et al., I953; Wolman. I964; Harvey, I967; White et al., I969; Ducker et al., I969; Tomasula et al., 1969; Ducker, I971; Dohrmann, 1972; Osterholm, 1972, I974; Hedeman et al., 1974; Perlman, 1974; Tator, I973; Naftchi et al., I974; Yeo et al., 1974).

The following is a short chronological review of a number of experimental studies carried out to elucidate the pathogenesis of the contusion injury to the mammalian spinal cord: 
In I890. Schmaus was the first to study in the experimental animal, the effects of concussion, rather than laceration to the spinal cord. He attached wooden boards to the backs of rabbits which were suspended vertically and after blows to the boards he reported areas of necrosis cavity formation and cystic degeneration (Schmaus, I890).

$I 89 I$. Watson dropped dogs from various heights in a specially constructed apparatus but was unable to duplicate the pathological findings reported by Schmaus (Watson, I89I).

I895. Bikeles in a similar experiment confirmed the findings of Schmaus (Bikeles, I895).

I897. Lugenberger was reported to produce degeneration of the anterolateral columns of white matter after contusion to the spinal cords of guinea-pigs (Schmaus, I897).

I897. Following blows to a rabbit's back, studies by Krichgasser (I897) and Scagliosi (1898) demonstrated degeneration in myelin sheaths and in the anterior horn cells, although there was no evidence of intramedullary haemorrhage or fractures of the vertebral column.

I899. After the injury to the spinal cord by squeezing the cat in a swinging door, Spiller (1899) reported degeneration in the anterior and anterolateral columns of the white matter.

1907. Stcherbak reported necrosis of the grey matter of the spinal cord after the application of a vibrating device (Stcherbak, 1907).

I9II. Allen was probably the first to injure the spinal cord directly when he developed a technique which produced an anticipated degree of spinal cord contusion in dogs. Quantitation and standardisation of the lesion was achieved when a known weight was dropped within a perpendicular tube from a calculated height on to the exposed spinal cord surrounded by intact dura. Allen reported that the contusion resulting from a 240 'grams-centimeter' impact resulted in an immediate spastic paraplegia which improved significantly within ten days. By increasing the weight to 400 'grams-centimeter' impact the degree of injury was more severe and a complete permanent spastic paraplegia resulted. Allen also reported significant recovery in a number of dogs when medial or longitudinal myelotomy was performed through the bruised segments. Hemorrhage and oedema was described in the grey and white matter within 15 minutes of the injury. After four hours, numerous swollen axons appeared in the lateral and posterior columns of white matter with increasing haemorrhage and oedema. Reducing the intramedullary tension with myelotomy appeared to improve the chances of clinical recovery in these animals. He suggested that the development of high intramedullary pressure from haemorrhage and oedema produced further ischaemic necrosis after the direct injury (Allen, I9II, I9I4).

I9I6. D'Abundo studied necrosis of the posterior columns of white matter of the spinal cord after centrifuging (D'Abundo, I9I6).

I9I8. Marinesco described medullary haemorrhages in the spinal cords of dogs which had been subjected to explosive forces (Marinesco, I918).

I919. Ayer produced compression in the spinal cords of cats by injecting paraffin into the epidural space. He reported a normal histological appearance apart from some meningeal inflammation although the animals suffered complete paraplegia (Ayer, 1919).

1920. Roussy struck the thoracic vertebral column in guinea-pigs and rabbits and described the results of this direct trauma on the myelinated fibres (Roussy et al., 1920). 
I923. Using dogs, McVeigh produced lesions by compressing the spinal cord with a fingertip at the $\mathrm{T}_{7} / \mathrm{T} 8$ level. He described the formation of oedema in the lateral and anterior columns within eight hours of the injury, increasing over the following two days. The intramedullary haemorrhage extended along the dorsal white columns and in the central grey matter above and below the level of the injury (McVeigh, I923).

I923. Thompson studied the spinal cords of cats following crushing with the tip of a finger and scalpel handle. He described a cone-shaped region of haemorrhage and degeneration which extended rostrally and caudally (Thompson, I923).

1927. Ferraro administered blows to the backs of rabbits with an iron rod and reported swollen axons in the spinal cord developing within one hour, followed by alterations in myelin sheaths within 12 hours. Four days after injury reactive gliosis and degeneration in the white matter were evident with changes in the anterior horn cells. He attributed the histopathology to shock waves produced by the blows and transmitted to the spinal cord by the cerebro-spinal fluid (Ferraro, I972).

1932. Craig inserted pieces of bone wax into the intradural space around spinal cord of the cat and reported degeneration in the posterior columns at the level of the compression with vacuolation and cystic degeneration extending caudally to the compression (Craig, I932).

1936. Amako, using a modification of Allen's method of impact injury, reported immediate haemorrhage in the grey matter with later cavity formation in the spinal cords of dogs (Amako, 1936).

I945. Cats were suspended vertically by Groat et al. (I945) and struck across the vertebral column with a board. He reported that the pathological and electrophysiological changes varied directly with the force employed.

1953. Freeman and Wright claimed that myelotomy of the contused spinal cord aided functional return in the experimental animal. They postulated that the oedema and haemorrhage caused further compression of the spinal cord tissue within the thecal membranes and myelotomy released this pressure (Freeman \& Wright, I953).

Between I953 and I957. Tarlov placed a small hydraulic balloon in the epidural space to apply a quantitative compressive force to the spinal cords of dogs. Both acute and chronic compression by the epidural balloon produced degeneration which extended rostrally and caudally. (Tarlov et al., I853, I954; Tarlov, 1954, 1957).

1956. Gelfan and Tarlov demonstrated that the conduction block following compression of the canine spinal cord was reversible. The disturbance of conduction appeared secondary to mechanical deformation rather than anoxia (Gelfan \& Tarlov, 1956).

1960. Kano found that by reducing the cross-sectional area of the canine spinal cord by as little as ro per cent he would produce degeneration of ganglion cells, nerve fibres and oedema (Kano, I960).

I96I. Kajiwara and Aikawa secured rabbits within a cylinder and dropped the cylinder from varying distances to study the histopathology of the contused spinal cord. Both authors reported intramedullary haemorrhage and oedema in the spinal cord (Kajiwara, K., I96r; Aikawa, 1967).

I963. Joyner and Freeman reported clinical improvement in cats when the use of an intravenous infusion of urea was given soon after the spinal cord was injured (Joyner \& Freeman, 1963). 
1967. Kamiya used intravascular injections of barium sulphate in cats to demonstrate the vascular changes which occurred after compression of the anterior cervical spinal cord with a variety of epidural devices (Kamiya, 1967).

Coe, Calvin and Rudenberg (1967) studied the electrophysiological responses of the monkey's spinal cord following cervical flexion compression. They attributed the immediate loss of the negative deflection of the primary evoked response to conduction alteration at the synaptic level in the injured segment of the spinal cord.

Harvey and Srebnik (1967) crushed the spinal cords of rats with thumb forceps and reported regeneration of nerve fibres and improvement in locomotion in those rats treated with levothyroxine prior to or after injury.

Scholte (1967) pierced the posterior columns of the spinal cord of rats with a razor blade and studied the spinal cord with the electron microscope. Nine hours after injury, plasma exudate was evident throughout the grey matter and in the extracellular spaces of the white matter.

Between I966 and 1969. Albin used a modified version of Allen's impact injury on the spinal cords of dogs and monkeys. He described oedema which rapidly developed, causing the injured cord to swell, and used localised hypothermia within four hours of the injury (Albin et al., 1966, I967, I968, I969). He demonstrated significant recovery in a series of 13 animals whose contused spinal cords were exposed to cooling under general anaesthesia for three hours (Albin, White \& Acosta-Rua, 1968). The cooling process was commenced four hours after the injury. Each of 13 animals in the control group remained paraplegic. When local hypothermia to the contused spinal cord was delayed for eight hours, no significant recovery occurred (Albin, White, Yashon et al., I968).

1968. Grossman reported abolition of the evoked cortical response one minute after the impact injury to the thoracic spinal cord of the dog (Grossman, 1968).

The importance of progressive disturbance of the microvasculature which could lead to further local hypoxia was now well recognised, and suggested as a reason for extension of the neurological deficit within hours of the spinal cord injury (Barnes, I948; Schneider, 1958; Bedbrook, I966; Osterholm \& Mathews, 1972; Vise, Yashon \& Hunt, 1974). With the quantitation of trauma and a known pathology profile, proposed methods of treatment could be assessed in the experimental animal. There was now a new emphasis to research physical and chemical methods of treatment in an attempt to reduce the pathological changes associated with profound paraplegia following the contusion injury to the spinal cord.

1969. Ducker and Hamit produced a contusion injury in beagles and reported thac parenteral administration of steroids by intramuscular injection was of value in preventing permanent paraplegia. They claimed local hypothermia and intramuscular steroids were useful to control cord swelling and improve clinical recovery, provided treatment was commenced within three hours of injury. Although both treated groups of animals improved significantly when compared with controls, the degree of recovery was not significantly different between each of the treated groups. Intrathecal methyl prednisolone (Depomedrol) also improved the neurological recovery but not as significantly as intramuscular steroids (Ducker \& Hamit, I969).

Donaghy and Numoto (1969), using dogs, reported recovery of cortical sensory evoked potentials from peroneal nerve stimulation within four hours of spinal cord contusion. The rapid return of the evoked potentials indicated future recovery of motor function. 
Hartzog et al. (1969) treated the contused spinal cord of the baboon with hyperbatic oxygen and reported functional recovery. Tomasula et al. (1969) reported a series of 67 cats subjected to a controlled contusion injury to the spinal cord. He demonstrated histo-fluorescence in the grey matter beyond the small areas of haemorrhage within two minutes of the injury. Fifteen minutes after the injury the entire grey matter and the major portion of the white matter was fluorescent under ultraviolet light. A study of the sequential pathological changes between two minutes and four hours after impact revealed progressive pathology and from then on the damage appeared irreparable. At 48 hours there was a total loss of anatomical continuity in the spinal cord tissue. $\mathrm{He}$ also reported after a survey on the management of experimental spinal cord trauma that the best recovery of function occurred after posterior myelotomy.

Using fluorescent techniques to study the intraspinal circulation in dogs, Wagner et al. demonstrated a decrease of as much as 50 per cent in the blood flow through the spinal cord soon after injury (Wagner, I969a, $b$ ).

Ducker \& Assenmacher (1970) and White \& Albin (I969a, b) reported initial extravasation of erythrocytes following the venous engorgement and stasis.

Coalescence of discreet haemorrhages with ischaemic changes in neurones were reported after a sequential pathological study by Goodkin and Campbell (1969).

1970. Kelly reported significant recovery in dogs with contused spinal cords after treatment with hyperbaric oxygen (Kelly et al., I970).

Singer, Russell and Coe (1970) reported an abolition of the evoked response through the injured portion of the spinal cord within 20 to 90 seconds after trauma. The response reappeared after 24 hours.

I97I. Black and Markowitz (I97I) observed that steroids enhanced the functional recovery in monkeys, while incision of the dura mater had a deleterious effect. Recovery rates were the same in monkeys decompressed with either a one or three level laminectomy.

Ducker and Perot (I97I) reported a decrease in intramedullary blood flow at one and two hours after contusion. They reported a decrease in spinal cord tissue oxygen concentration in the traumatised segment within two to three hours. Further description of the intramedullary haemorrhage and oedema of the spinal cord was reported in cats by Richardson and Nakamura (I97I) using the electron microscope. They reported an increase in the size of the basement membranes and a swelling of the astrocytic processes with an increase in the extracellular space. A combination of local hypothermia and steroids appeared to reverse all of these pathological changes.

Tator (I97I) described demyelination largely in the lateral white matter with cavitation in the grey over several months after compression of the spinal cord in monkeys.

Wagner, Dohrmann and Bucy (1970, I97I) described the leakage of erythrocytes into the perivascular space surrounding thin wall vessels in the central grey matter.

Using light microscopy, Yeo, Payne and Collins (I97I) reported that white matter adjacent to the neural tissue injured directly by impact to the spinal cord of the sheep demonstrated progressive swelling of axon fibres and disruption of myelin sheaths over four hours. Congestion and extravasation was evident as early as 15 to 30 minutes and progressed in both white and grey matter over two hours. By four hours there appeared to be generalised irreversible damage to 
myelinated nerve tissue. Fairholm and Turnbull (I970, I97I) as well as Assenmacher and Ducker (I97I) also described coalescence of discreet haemorrhages with ischaemic changes occurring in the anterior horn cells. They demonstrated non-filling of most small vessels within the central grey and white matter lying beneath.

Locke et al. (I97I) described an increase in spinal cord lactate associated with ischaemia following contusion injury in monkeys. Many other workers, including Ducker, Kindt and Kempe (I97I), continued to report on these dynamic pathological findings in the acute experimental spinal cord trauma. Dohrmann, Wagner and Bucy (I97I $a, b, c)$ reported studies of the experimental contusion in the spinal cord of the monkey and cat with electron and light microscopy. The muscular venules were found to have tears in their walls as early as 15 minutes after the contusion and these tears were identified as the source of some of the very early perivascular extravasation. By four hours the endothelium of the capillaries was swollen, although the walls appeared intact. Within several hours after the contusion, ultra-structural alterations in periaxonal spaces and axonal degeneration were reported. They also reported the perfusion of grey matter was reduced within I 5 minutes and after one hour the blood flow was non-existent. Although they described alterations in the blood flow in the white matter within one hour of the contusion the blood flow appeared to return to normal within 24 hours. Dohrmann and Wick (I97I) reported the transient decrease in blood flow in the white matter occurred as early as five minutes and was persistent for one hour.

Fried and Goodkin (197I), using barium sulphate studies, demonstrated progressive lack of perfusion and this severe disturbance of normal haemodynamics was still evident 24 hours after the injury. Turnbull (I97I) described the central vessels of the spinal cord as susceptible to stretching and compression by a posteroanterior force. Green and Wagner (I97I) reported the development of oedema in cats, initially in the grey and later in the white matter, within the first eight hours of the injury. After one hour the oedema appeared primarily to involve they grey matter but by four hours the white matter immediately adjacent to the grey matter was also involved. Within eight hours the entire contused section of the spinal cord was described as 'oedematous'.

Campbell et al. (I97I) studied evoked cortical potentials in cats and demonstrated that, if the potentials were evident within three hours of the injury, recovery would follow.

I97I-I972. Osterholm was the first to suggest that local accumulation of noradrenaline following injury could result in further progressive damage to neurones adjacent to the nerve tissue damaged by the initial blow. He reported a fourfold rise in the level of noradrenaline in the cat's spinal cord within one hour of injury. In this period the levels of dopamine were shown to fall. By locking noradrenaline synthesis and release with intravenous administration of alpha methyl tyrosine, Osterholm demonstrated a marked reduction in the pathology found in both grey and white matter. The recovery in the treated animals was recorded as significantly improved when compared with the recovery in the control group of animals (Osterholm, I971, I972).

In 1972, Kelly reported significant recovery from induced paraplegia in dogs with hyperbaric oxygen (Kelly et al., 1972).

Tarlov (1972) stated that irreversible conduction block following compression of the spinal cord of the cat was secondary to mechanical deformation and not due to hypoxia. 
1973. Di Chiro and Wener reviewed the detailed angiographic anatomy which is important in the interpretation of the pathology of spinal cord injury.

Tator and Deecke (1973) demonstrated in monkeys that local perfusion of the injured spinal cord with cooled and non-cooled Elliots ' $B$ ' solution produced significantly better restoration of function than was found in similarly wounded non-perfused animals. They suggested that perfusion dialysis of some noxious chemical material from the wounded cord occurred and this thesis would have supported much of the work reported by Osterholm.

Martin and Blodell (1973) evaluated the experimental spinal cord injury using cortical evoked potentials. They concluded that bilateral normal sensoryevoked potentials should indicate functional and probably structural integrity of the posterior half of the spinal cord.

Dohrmann and Wick (1973) documented the fact that the smaller vessels in both the central grey and white matter at the level of the injury did not fill, strongly suggesting the presence of local retardation or arrested blood flow.

1974. Vise, using fluorescent microscopy with Evans blue as a tracer, reported a defective blood-brain barrier in dogs immediately following spinal cord injury.

Since the publication of Osterholm's work in I97I, many other workers have been unable to confirm the reported rise of noradrenaline in contused spinal cord tissue (Hedeman \& Shellenberger, I973; Naftchi et al., I974; Vise et al., I974; Hinwood et al., I974; Yeo et al., 1974).

Until ten years ago little was known of the early dynamic pathological changes which occurred in the bruised mammalian spinal cord. As yet, it is still not possible to know exactly what happens to the contused human spinal cord and information must continue to be obtained from the experimental animal. Isotope myelography has been reported as a useful investigation to help identify spinal cord swelling and contusion (Yeo \& Collins, I974).

This brief historical review summarises many of the studies which are being made in animals whose nervous systems closely resemble that of man. The best choice for such studies would be the ape, although expensive and difficult to nurse satisfactorily for long periods. In this country the sheep has proved an adequate experimental model with a suitably sized spinal cord and a satisfactory animal for nursing in slings. A detailed assessment of clinical recovery in the control and treated animals has been possible and the animals nursed for long periods without significant complications (Yeo et al., I971, I974, I975).

Much of the basic research work in recent years has been centred on the catecholamine release theory with progressive neurological damage in the region of the initial spinal cord injury. Drugs such as Alpha methyl tyrosine have been found to be highly effective in preventing acute noradrenaline hyperaccumulation and when given I 5 minutes after the injury protect against haemorrhagic necrosis in injured spinal cord tissue (Osterholm, I972). Why Alpha methyl tyrosine is so effective in animal experiments during the acute phases of treatment while subacute and chronic injured and treated cords often become severely degenerated remains an unanswered question. Hedeman and Shellenberger were unable to detect any protection from single treatments of AMT in chronic dog studies (Hedeman and Shellenberger, 1973). Other forms of treatment which have been tried in recent years are anti-fibrinolytic therapy, hyperbaric oxygen and antiserontonic therapy. The results of these experiments have been summarised in an excellent review article by Osterholm (1974). Many of these physical and drug treatments in the experimental animal have been promising but are not yet applicable to the paraplegic or quadriplegic patient. 


\section{REFERENCES}

Aikawa, Y. (1967). Experimental study on the spinal cord injury. Iryo, 2I, 542-549.

Albin, M. S., White, R. J., Locke, G. E. \& KRETChMeR, H. E. (I966). Spinal cord hypothermia by localised perfusion cooling. Nature, 2 I0, 1059.

Albin, M. S., White, R. J., Locke, G. S. et al, (1967). Localized spinal cord hypothermia: Anesthetic effects and application to traumatic injury. Anesth. Analg. 46, 8-16.

Albin, M. S., White, R. J., Yashon, D. et al. (I968). Functional and electrophysilogic limitations of delayed spinal cord cooling after impact injury. Surg. Forum, I9, 423-424.

Albin, M. S., White, R. J., Yashon, D. et al. (I969). Effects of localized cooling on spinal cord trauma. F. Trauma, 9, I000-1008.

Albin, M. S., White, R. J., Acosta-RuA, G. et al. (1968). Study of functional recovery produced by delayed localized cooling after spinal cord injury in primates. F. Neurosurg. 29, I I 3-I 20.

AlleN, A. R. (I9II). Surgery of experimental lesion of spinal cord equivalent to crush injury of fracture dislocation of spinal column: A preliminary report. F.A.M.A. 57, 878-880.

Allen, A. R. (I9I4). Remarks on the histopathological changes in the spinal cord due to impact. An experimental study. F. Nerv. Ment. Dis. 41, I4I-I47.

AмaKo, T. (1936). Surgical treatment of spinal cord injury by blunt forces; experimental study. F. Fap. Surg. Soc. 37, I843-1874.

AssenMACHER, D. R. \& Ducker, T. B. (I97I). Experimental traumatic paraplegia: The vascular and pathological changes seen in reversible and irreversible spinal cord lesions. F. Bone foint Surg. 53A, 671-680.

AYER, J. B. (1919). Cerebrospinal fluid in experimental compression of the spinal cord. Arch. Neurol. Psychiat. 2, I 58-I64.

BARNes, R. (1948). Paraplegia in cervical spinal injuries. F. Bone foint Surg . 30B, 234-244.

BeDbrook, G. M. (1966). Pathological principles in the management of spinal cord trauma. Paraplegia, 4, 43-56.

Bikeles, G. (I895). Zur pathologischen anatomie der Hirn- und Ruckenmarkserschutterung. Neurol. Centralbl. 14, 463-464.

BLACK, P. \& MARKowità, R. S. (I97I). Experimental spinal cord injury in monkeys; comparison of steroids and local hypothermia. Surg. Forum, 22, 409-4I I.

Campbell, J. B., DeCrescito, V., Tomasula, J. J. (I97I). Bioelectric prediction of 'permanent post-traumatic paraplegia. Read before the 1971 meeting of the American Association of Neurological Surgeons, Houston, 20 April.

Coe, J. E., Calvin, T. H. JR., Rudenberg, F. H. et al. (I967). Concussion-like state following cervical cord injury in the monkey. F. Trauma, 7, 512-522.

Craig, W. MCK. (I932). Pathology of experimental compression of the spinal cord. Proc. Staff Meet. Mayo Clin. 7, 680-682.

D'ABUnDo, G. (1966). Alterazioni nel sistma nervoso centrale consecutive a particolari commonzioni traumatiche. Riv. Ital. Neuropat. 9, I45-I7I.

Di ChIro, G. \& WeNER, L. (1973). Angiography of the spinal cord: A review. F. Neurosurg. 39, I-29.

Dohrmann, G. J., Wagner, F. C. JR. \& BuCY, P. C. (I97I $a$ ). Fine structure of myelinated nerve fibers in transitory traumatic paraplegia. Fed. Proc. 30, 287.

DohrmanN, G. J., WAGNER, F. C. JR. \& BUCY, P. C. (I97I $b$ ). The microvasculature in transitory traumatic paraplegia: An electron microscopic study in the monkey. $\mathcal{F}$. Neurosurg. 35, 263-27I.

DohrmanN, G. J., WAGNER, F. C. JF. \& BucY, P. C. (I97Ic). Transitory traumatic paraplegia: An electron microscopic study in the monkey. Proc. New Zealand Soc. Electron Micr. 4, 19.

DorhmanN, G. J. \& WICK, K. M. (I97I). Demonstration of the microvasculature of the spinal cord by an intravenous injection of the fluorescent dye, thioflavine. S. Stain Technol. 46, 42I-322.

Dohrmann, G. J. \& WICK, K. M. (I97I). Electron microscopy and blood flow studies in experimental spinal cord trauma. Read before the All India Institute of Medical Sciences, New Delhi, India, 29 April.

Dohrmann, G. J., WAGNER, F. C. JR., WICK, K. M. et al. (I97I). Fine structural alterations in transitory traumatic paraplegia. Proc. Veterans Adm. Spinal Cord Inj. Conf. 18, 6-8. 
Dohrmann, G. J., Wick, K. M. \& BuCY, P. C. (I973). Spinal cord blood flow patterns in experimental traumatic paraplegia. $\mathcal{F}$. Neurosurg. 38, 52-58.

DoHRMANN, C. J. \& WICK, K. M. (I973). Intramedullary blood flow patterns in transitory traumatic paraplegia. Surg. Neurol. I, 209-2I5.

Dohrmann, C. J., Wagner, F. C. JR. \& BUCY, P. C. (1972). Transitory traumatic paraplegia: Electron microscopy of early alterations in myelinated nerve fibers. F. Neurosurg. 36, 407-4I5.

Donaghy, R. M. P. \& Numoto, M. (1969). Prognostic significance of sensory evoked potential in spinal cord injury. Proc. Annu. Clin. Spinal Cord Inj. Conf. 17, 25I257.

DuCKER, T. B. \& HAMIT, H. F. (1969). Experimental treatments of acute spinal cord injury. F. Neurosurg. 30, 393-397.

DUCKER, T. B. \& AssENMACHER, D. (I969a). The pathological circulation in experimental spinal cord injury. Proc. Annu. Clin. Spinal Cord Inj. Conf. I7, Io-I I.

DuCKeR, T. B. \& Assenmacher, D. R. (I969b). Microvascular response to experimental spinal cord trauma. Surg. Forum, 20, 428-430.

Ducker, T. B., Kindt, G. W. \& Kempe, L. G. (I97I). Pathological findings in acute experimental spinal cord trauma. F. Neurosurg. 35, 700-708.

Ducker, T. B. \& Perot, P. L. JR. (I97I). Spinal cord oxygen and blood flow in trauma. Surg. Forum, 22, 413-4I5.

FAIRHOLM, D. J. \& TURNBULL, I. M. (I97I). Microangiographic study of experimental spinal cord injuries. F. Neurosurg. 35, 277-286.

FaIRHOLM, D. \& TURNBULl, I. (I970). Microangiographic study of experimental spinal injuries in dogs and rabbits. Surg. Forum, 21, 453-455.

FERRARO, A. (1927). Experimental medullary concussion of the spinal cord in rabbits. Histologic study of the early stages. Arch. Neurol. Psychiat. 18, 357-373.

FrEEMAN, L. W. \& WRIGHT, T. W. (I953). Experimental observations of concussion and contusion of the spinal cord. Ann. Surg. 137, 433-443.

FRIED, L. C. \& GoODKIN, R. (I97I). Microangiographic observations in the experimentally traumatized spinal cord. $\mathcal{f}$. Neurosurg. 35, 709-7I4.

Gelfan, S. \& TARLov, I. M. (1956). Physiology of spinal cord nerve root and peripheral nerve compression. Am. F. Physiol. 185, 217-229.

Goodkin, R. \& CAMPBell, J. B. (I969). Sequential pathological changes in spinal cord injury. A preliminary report. Surg. Forum, 20, 430-432.

Grossman, M., White, R., TASLITZ, N. et al. (I968). Electrophysiological responses immediately after experimental injury to the spinal cord. Anat. Rec. 160, 473.

GreEN, B. A., WAGNER, F. C. JR. \& BUCY, P. C. (I97I). Edema formation within the spinal cord. Trans. Am. Neurol. Assoc. 96, 244-245.

Groat, R. A., Rambach, W. A. JR. \& Windle, W. F. (I945). Concussion of the spinal cord. Surg. Gynaecol. Obstet. 81, 63-74.

HARTZOG, J. T., Fisher, R. G. \& SNOW, C. (I969). Spinal cord trauma; effect of hyperbaric oxygen therapy. Proc. Annu. Clin. Spinal Cord Inj. Conf. 17, 70-71.

HARVEY, J. E. \& SREBNik, H. H. (1967). Locomotor activity and axon regeneration following spinal cord compression in rats treated with L-thyroxine. $\mathcal{F}$. Neuropathol. Exp. Neurol, 26, 661-668.

HeDEMAN, L. S. \& SHellenberger, M. D. (1973). Experimental spinal cord trauma catecholamine levels and treatment with low molecular weight Dextran and various catecholamine blockers. Presented to the 4Ist Annual Meeting of the American Assoc. of Neurological Surgeons, Los Angeles, April.

Hedeman, L. S. \& RahajIT, S. K. (I974). F. Neurosurg. 40, 44-5I.

Hinwood, B., Yeo, J. \& Kidman, A. D. (I974). Catecholamine levels in the sheeps spinal cord following trauma. Proc. of the Australian Biochemistry Society, 7, 7.

Hughes, J. T. (1966). Pathology of the Spinal Cord. Lloyd-Luke.

JOYNER, J. \& FREEMAN, L. W. (I963). Urea and spinal cord trauma. Neurol. 13, 69-72.

KajIWARA, K. (196I). An experimental study on the spinal cord injuries. Funtendo Med. F. 7, 612-618.

KAMIYA, T. (1967). Experimental study on anterior spinal cord compression with special emphasis on vascular disturbance. Nagoya F. Med. Sci. 31, I7I-I90.

Kano, S. (1960). Experimental studies on paralysis caused by compression of the spinal cord. f. Nagoya Med. Assoc. 82, 64I-656.

Kelly, D. L., LASSiter, K. R. L., CAlOgero, J. A. et al. (I970). Effects of local hypothermia and tissue oxygen studies in experimental paraplegia. $\mathcal{F}$. Neurosurg. 33, 554563. 
Kelly, D. L., Lassiter, K. R. L., Vongsvivut, A. et al. (1972). Effects of hyperbaric oxygenation and tissue oxygen studies in experimental paraplegia. F. Neurosurg. 36, 425-429.

KIRCHGASSER, G. (I897). Experimentalle Untersuchungen uber Ruckenmarkserschutterung. Deutsche Z. Nervneh, II, 408-4I9.

Locke, G. E., YASHON, D., FeldMAN, R. A. et al. (I97I). Ischemia in primate spinal cord injury. F. Neurosurg. 34, 6I4-6I7.

LUI, C. N. \& CHAMBERs, W. W. (I958). In raspinal sprouting of dorsal root axons; development of new collaterals and preterminals following partial denervation of the spinal cord in the Cat. Archives Neurol. Psych. 79, 46-6r.

MARINESCO, G. (I9I8). Lesions commotionnelles experimentales. Rev. Neurol. 34, 329$33 \mathrm{I}$.

MaRTIN, S. H. \& BLOEDEL, J. R. (I973). Evaluation of experimental spinal cord injury using cortical evoked potentials. F.A.M.A. 129, I52-153.

McVeigh, J. F. (I923). Experimental cord crushes with special reference to the mechanical factors involved and subsequent changes in the areas of the cord affected. Arch. Surg. 7, 573-600.

Naftchi, N. E., Demeny, M., Decrescito, V., Tomasula, J., Flamm, E. \& Campbell, J. (1974). Biogenic amine concentration in traumatised spinal cords of cats. F. Neurosurg. 40, 52-57.

OSTERHOLM, J. L. \& MATHEWS, G. J. (I97I). A proposed biochemical mechanism for traumatic spinal cord haemorrhagic necrosis; successful therapy for severe injuries by metabolic blockade. Trans. Am. Neurol. Assoc. 96, I87-191.

Osterholm, J. L., Mathews, G. F., Irvin, J. D. et al. (I97I). A review of altered norepinephrine metabolism attending severe spinal injury: Results of alpha methyl tyrosine treatment and preliminary histofluorescent studies. Proc. Veterans Adm. Spinal Cord Inj. Conf. 18, 17-21.

OSTERHOLM, J. L. \& MATHEWs, G. J. (1972). Altered norepinephrine metabolism following experimental spinal cord injury. I. Relationship to haemorrhagic necrosis and postwounding neurological deficits. F. Neurosurg. 36, 386-394.

Osterholm, J. L. \& MATHEWs, G. J. (I972). Altered norepinephrine metabolism following experimental spinal cord injury. II. Protection against traumatic spinal cord haemorrhagic necrosis by norepinephrine synthesis blockade with alpha methyl tyrosine. $\mathcal{F}$. Neurosurg. 36, 395-40I.

OsterHOLM, J. L. (I974). The pathophysiological response to spinal cord injury-current status. F. Neurosurg. 40, 5-33.

Perlman, S. G. (1974). Spinal cord injury-a review. Arch. Phys. Med. Rehabil. 55, $8 \mathrm{I}-87$.

RichaRdSON, H. D. \& NAKAMURA, S. (I97I). An electron microscopic study of the spinal cord edema and the effect of treatment with steroids, mannitol and hypothermia. Proc. Veterans Adm. Spinal Cord Inj. Conf. 18, IO-I6.

Roussy, G., L'Hermitte, J. \& Cornil, L. (I920). Etude experimentale des lesions commotionelles de la moelle spiniere. Ann. Med. 8, 335-353.

SCAGLIOSI, G. (I898). Ueber die Gehimerschutterung und die daraus im Gehim und Ruckenmark hevorgerufenen histologischen veranderungen. Virchows Arch. 152, 487-525.

Schmaus, H. (1890). Beitrage zur pathologischen Anatomie der Ruckenmarkserschutterung. Virchows Arch. 122, 470-495.

SCHNEIDER, R. D. (I958). The syndrome of acute central cervical spinal cord injury. f. Neurol. Neurosurg. Psychiat. 21, 2 I6.

Scholte, W. (1967). Plasmatische infiltration der extra-und intracellularraume der gauen substanz (Plasmatische Infiltrationsnekrose) nach experimentallen Trauma. Acta Neuropath. 8, I7I-I84.

Singer, J. M., Russel, G. V. \& CoE, J. E. (I970). Changes in evoked potentials after experimental cervical spinal cord injury in the monkey. Exp. Neurol. 29, 449-46I.

SPILLER, W. G. (I899). A critical summary of recent literature on concussion of the spinal cord with some original observations. Am. F. Med. Sci. 118, 190-198.

STCHERBAK, A. (1907). Des alterations de la moelle epineire chez le lapin sous l'influence de la vibration intensive: Valeur diagnostique du clonus vibratoire: Contribution a l'étude de la commotion de la moelle epiniere. Encephale, 2, 5 I2-535.

Tarlov, I. M., Klinger, H. \& Vitale, S. (I953). Spinal cord compression studies: I. Experimental techniques to produce acture and gradual compression. Arch. Neurol. Psychiat. 70, 813-8I9. 
TARLov, I. M. \& Klinger, H. (I954). Spinal cord compression studies: II. Time limits for recovery after acute compression in dogs. Arch. Neurol. Psychiat. 7I, 271-290.

TARLOv, I. M. (I954). Spinal cord compression studies: III. Time limits for recovery after gradual compression in dogs. Arch. Neurol. Psychiat. 71, 588-597.

TARLov, I. M. (1957). Spinal Cord Compression: Mechanism of Paralysis and Treatment. Springfield, Ill.: Charles C. Thomas.

TARLov, I. M. (1972). Acute spinal cord compression paralysis. F. Neurosurg. 36, 10-20.

TATOR, C. H. \& DEECKE, L. (I973). Value of normothermic perfusion and durotomy in the treatment of experimental acute spinal cord trauma. F. Neurosurg. 39, 52-64.

TAtoR, C. H. (I97I). Experimental circumferential compression injury of primate spinal cord. Proc. Annu. Clin. Spinal Cord Inj. Conf. pp. 2-5.

Thompson, J. E. (1923). Pathological changes occurring in the spinal cord, following fracture dislocation of the vertebrae. Ann. Surg. 78, 260-293.

Tomasula, J. J., De Crescito, V., Goodkin, R. et al. (I969). A survey of the management of experimental spinal cord trauma. Proc. Annu. Clin. Spinal Cord Inj. Conf. 71, I2-I6.

Turnbuli, I. M. (I97I). Microvasculature of the human spinal cord. F. Neurosurg. 35, I4I-I 47.

VISE, W. M., YASHON, D. \& HUNT, W. E. (1974). Mechanisms of norepinephrine accumulation within sites of spinal cord injury. $\mathcal{F}$. Neurosurg. 40, 76-82.

WAGNer, F. C. JR., Dohrmann, G. J., TAsLitz, N. et al. (I969a). Histopathology of experimental spinal cord trauma. Proc. Annu. Clin. Spinal Cord Inj. Conf. 17, 8-Io.

WAgNeR, F., TASLITZ, N., White, R. J. et al. (1969b). Vascular phenomena in the normal and traumatized spinal cord. Anat. Rec. I63, $28 \mathrm{I}$.

Wagner, F. C. JR., Dohrmann, G. J. \& BuCy, P. C. (I970). Early alterations in spinal cord morphology following experimental trauma. Fed. Proc. 29, 289.

Wagner, F. C. JR., DohrmanN, G. J. \& BUCY, P. C. (I97I). Histopathology of transitory traumatic paraplegic in the monkey. F. Neurosurg. 35, 272-276.

Watson, B. A. (I89I). An experimental study of lesions arising from severe concussions. Centralbl. Allgem. Pathol. 2, 74.

White, R. J., AlbiN, M. S., HARRIS, L. S. et al. (1969). Spinal cord injury: Sequential morphology and hypothermia stabilization. Surg. Forum, 20, 432-434.

White, R. J. \& Albin, M. S. (I970). Spine and spinal cord injury, in Gurdjian, E. S., Lane, W. A., Patrick, L. M. (Eds): Impact Injury and Crash Protection. Springfield, Ill.: Charles C. Thomas, pp. 63-85.

WindLE, W. F. (1955). Regeneration in the Central Nervous System. Springfield, Ill.: Charles C. Thomas.

WINDLE, W. F. (1962). Basic Research in Paraplegia, edited by J. D. French \& R. W. Potter. Springfield, Ill.: Charles C. Thomas, p. 5.

Wolman, L. (1964). The neuropathology of traumatic paraplegia. A critical historical review. Paraplegia, $\mathbf{1}, 322-25 \mathrm{I}$.

Wolman, L. (1966). Axon regeneration after spinal cord injury. Paraplegia, 4, 3, I75-I 84.

Yeo, J. D., PAYNe, W. \& Collins, L. T. (I97I). Controlled experimental contusion of the spinal cord of sheep. Proceedings of the Surgical Research Society of Australasian Scientific Meeting, Aust. E N.Z. F. of Surgery, 4I, 89-90.

Yeo, J. D. \& Colins, L. (I974). The place of isotope myelography in the definition of spinal cord swelling following trauma. Aust. E N.Z. F. of Surgery, 44, 292-298.

Yeo, J. D., Payne, W., Hinwood, B. \& Kidman, A. D. (I974). Experimental spinal cord contusion. Proceedings of the Australian Society for Medical Research, Clinical $\mathcal{E}$ Experimental Pharmacology and Physiology-in press.

Yeo, J. D. \& PAYNE, W. H. (I975). Sequential pathological changes seen in controlled trauma to the spinal cord of the sheep. Ann. Meeting Royal College of Pathologists of Aust., Auckland, N.Z. F. Pathology, 7, 66.

Yeo, J. D., Payne, W. \& Hinwood, B. (I975). The experimental contusion injury of the spinal cord in sheep. Paraplegia, 12, 275-295. 